\title{
Pengaruh Kecerdasan Intelektual, Emosional, Dan Spritual Terhadap Kinerja Pegawai Balai Besar Pom Di Banda Aceh
}

\author{
(The Influence Of Intellectual, Emotional, And Spiritual Intelligences On \\ Performance Of Employees At Banda Aceh National Agency Of Drug $\mathcal{E}$ \\ Food Control)
}

Oleh:

\author{
Kiki Hendra Sitepu1), Achmad Fauzi 2), Zainur Hidayah ${ }^{3)}$ \\ hendra.sitepu@gmail.com ${ }^{1)}$, achmad_fauzioke@yahoo.com ${ }^{2}$, zainur@ecampus.ut.ac.id ${ }^{3)}$ \\ Universitas Terbuka1,2,3)
}

Submit: 12 Dec 2020

Review: 14 Dec 2020

Accept: 22 Dec 2020

Publish: 24 Dec 2020

\begin{abstract}
ABSTRAK
Kecerdasan sering dipahami oleh masyarakat sebagai kemampuan seseorang dalam proses berfikir. Proses berfikir disini dilakukan untuk memperoleh pengetahuan yang lebih dalam. Pengetahuan yang diperoleh akan menjadi landasan mencapai kesuksesan. Banyak yang menganggap bahwa orang cerdas dalam intelektual akan sukses dalam bekerja. Tetapi, kinerja seseorang tidak hanya ditentukan dari kecerdasan intelektual saja, melainkan adanya dukungan dari kecerdasan lain, yaitu emosional dan spiritual. Penelitian ini bertujuan untuk menganalisis pengaruh kecerdasan intelektual, emosional, dan spiritual terhadap kinerja. Pada penelitian ini sampel populasi adalah seluruh pegawai Balai Besar $\mathcal{E}$ Loka POM di Aceh yang berjumlah 157 orang dengan sampel yang diambil sebanyak minimal 60 sampel dengan menggunakan teknik probability sampling dimana semua elemen populasi punya kesempatan untuk dijadikan sebuah sampel. Pengumpulan data sampel menggunakan sistem angket. Analisis data menggunakan regresi linier berganda dan diolah menggunakan aplikasi SPSS versi 23. Hasil penelitian menunjukkan bahwa kecerdasan intelektual, kecerdasan emosional, dan kecerdasan spiritual berpengaruh terhadap variabel dependen kinerja pegawai.
\end{abstract}

Kata kunci :

kecerdasaan; intelektual; emosional; spiritual; kinerja

\begin{abstract}
Society defines intelligence as the thinking ability of an individual. The thinking process is conducted to gain in-depth knowledge. The knowledge gained will be the foundation for success. Many people think that intelligence in intellectual will be successful at work. Working performance is not only determined by intellectual intelligence but also from other bits of intelligence, namely emotional and spiritual intelligence. This study aims to determine the effect of intellectual, emotional, and spiritual intelligence on working performance. In this study, the population sample was all employees of Balai Besar $\mathcal{E}$ Loka
\end{abstract}


POM in Aceh, 157 people in total with 60 samples taken using probability sampling techniques where all elements of the population had the opportunity as a sample. In addition, the sample of data collection used questionnaires. Moreover, the data analysis used multiple linear regression and processed using SPSS version 23 application. The findings show that intellectual intelligence, emotional intelligence, and spiritual intelligence affect the dependent variable on the working performance of employees.

\section{Keywords:}

intelligence; intellectual; emotional; spiritual; performance.

\section{PENDAHULUAN}

Kecerdasan ialah istilah umum yang digunakan untuk menjelaskan sifat pikiran yang mencakup sejumlah kemampuan, seperti kemampuan menalar, merencanakan, memecahkan masalah, berpikir abstrak, memahami gagasan, menggunakan bahasa, dan belajar. Kecerdasan biasanya merujuk pada kemampuan atau kapasitas mental dalam berpikir, namun belum terdapat definisi yang memuaskan mengenai kecerdasan. Ada hal selain kecerdasan yang dapat mempengaruhi kinerja seseorang, yaitu kecerdasan emosi. Namun tidak semua ahli sepakat dengan hal ini karena berdasarkan penelitian yang dilakukan oleh Gordon (2004) menyebutkan bahwa meningkatkan kinerja didapat dari melihat kemampuan analisis dan kognitifnya bukan berdasarkan kepribadian dan suasana hati. Namun, Kecerdasan emosi dapat digunakan untuk pengembangan dalam peningkatan fungsi Sumber Daya Manusia, mulai dari proses rekrutmen, peningkatan kompetensi dan pengembangan karir hingga penilaian kinerja. Jadi, apabila dua hal tersebut dikombinasikan maka akan membuat kompetensi teknis serta produktivitas dan kinerjanya ikut meningkat.

Selain dua kecerdasan diatas, ada kecerdasan yang tidak kalah penting yaitu kecerdasan spritual. Kecerdasan tersebut membuat seseorang untuk mempunyai kreatifitas yang lebih, menciptakan dan melakukan perubahan aturan, yang membuat performa bekerja lebih baik. Dengan adanya kecerdasan spiritual, menjadi pelengkap manusia yang memiliki intelektual, emosional dan spiritual (Zohar dan Marshal, 2001). Namun Adlin (2002) memiliki pendapat yang berbeda mengenai hal ini, ia berpendapat bahwa menyandingkan terminologi spiritual dengan $Q$ ketiga dalam kecerdasan dan mengaitkannya dengan kinerja merupakan sebuah kekeliruan.

Kecerdasan sering dipahami oleh masyarakat sebagai kemampuan seseorang dalam proses berfikir. Proses berfikir disini dilakukan untuk memperoleh pengetahuan yang lebih dalam. Pengetahuan yang diperoleh akan menjadi landasan mencapai kesuksesan. Banyak yang menganggap bahwa orang cerdas dalam intelektual akan sukses. Namun, kesuksesan seseorang tidak hanya ditentukan dari kecerdasan intelektual saja, melainkan adanya dukungan dari kecerdasan lain. Kecerdasan tersebut adalah kecerdasan emosional dan kecerdasan spiritual. Ketiga kecerdasan ini terdapat didalam diri setiap individu, dan akan berkembang jika dapat mengasahnya dengan baik. Dalam prakteknya, ketiga kecerdasan ini memiliki kelebihan dan kekurangan masing-masing.

Badan Pengawas Obat dan Makanan, yang selanjutnya disingkat BPOM adalah 
lembaga pemerintah nonkementerian yang menyelenggarakan urusan pemerintahan di bidang pengawasan Obat dan Makanan. BPOM berada di bawah dan bertanggung jawab kepada Presiden melalui menteri yang menyelenggarakan urusan pemerintahan di bidang kesehatan. BPOM mempunyai tugas menyelenggarakan tugas pemerintahan di bidang pengawasan Obat dan Makanan sesuai dengan ketentuan peraturan perundangundangan. Obat dan Makanan terdiri atas obat, bahan obat, narkotika, psikotropika, prekursor, zat adiktif, obat tradisional, suplemen kesehatan, kosmetik, dan pangan olahan.

BPOM memiliki 73 Unit Pelasana Teknis yang tersebar di 34 Provinsi dan 40 Kabupaten di seluruh Indonesia. Salah satu UPT Teknis yang berada di pulau Sumatera yaitu Balai Besar Pengawas Obat dan Makanan (BBPOM) di Banda Aceh, yaitu salah satu Satuan kerja yang bersifat mandiri yang melaksanakan tugas teknis operasional tertentu dan / atau tugas teknis operasional tertentu dibidang pengawasan obat dan makanan.

Balai Besar Pengawas Obat dan Makanan di Banda Aceh mempunyai keunggulan dari UPT Balai Besar POM di Provinsi lain karena Laboratorium pengujian yang dimiliki oleh Balai Besar POM di Banda Aceh merupakan Laboratorium rujukan untuk pengujian/ Identifikasi fragmen DNA Babi dan Identifikasi ganja di wilayah regional barat Indonesia.

Di sisi lain Provinsi Aceh dengan julukan Serambi Mekkah mempunyai nilai-nilai budaya religious dengan mengedepankan spiritualitas dalam beragama. spiritualitas menggambarkan kualitas hidup yang mencakup tanggung jawab, kesejahteraan dan kesehatan spiritual dalam berbagai pengalaman agama.

Berdasarkan penjelasan mengenai permasalahan yang telah disebutkan maka peneliti ingin mengetahui bagaimana pengaruh kecerdasan intelektual, kecerdasan emosi dan kecerdasan spiritual pada pegawai Balai Besar POM di Banda Aceh terhadap kinerja pegawai.

\section{METODE PENELITIAN}

Penelitian ini menggunakan metode kuantitatif dengan sampel populasi adalah seluruh pegawai Balai Besar \& Loka POM di Aceh yang berjumlah 157 orang dengan sampel yang diambil sebanyak minimal 60 sampel. Teknik pengambil sampel yang digunakan dalam penelitian ini adalah probability sampling. Yaitu sebuah Teknik pengambil sampel dimana semua elemen populasi punya kesempatan untuk dijadikan sebuah sampel. Probabilty sampling yang digunakan adalah stratified random sampling, yaitu pengambilan sampel acak dengan memperhitungkan strata dalam populasi.

Peneliti memperoleh data dengan menyebarkan kuesioner menggunakan skala likert. Skala likert sendiri digunakan sebagai tolak ukur sikap, pendapat, dan persepsi, individu tau sekelompok individu tentang sebuah fenomena. Dengan skala ini variabel akan dipilah menjadi 19 indikator variabel, yang mana indikator tersebut akan digunakan menjadi titik tolak penyusunan item-item instrument yang berupa pertanyaan dan pernyataan. Data yang telah terkumpul dari hasil jawaban kuesioner yang disebarkan dilakukan uji validitas dan uji realibilitas.

Agar hasil analisis regresi nantinya dapat memenuhi kriteria best, linear, dan juga agar variabel independent yang 
menjadi estimator tidaklah bias maka dilakukan Uji Asumsi Klasik. Pengujian asumsi klasik ini terdiri atas pengujian autokorelasi, heteroskedastisitas, multikoliniaritas dan normalitas. 1) Uji Heteroskedatik terjadi jika terdapat kesamaan deviasi standar nilai variabel dependent pada variabel independent, jika terdapat kesamaan deviasi standar nilai variabel dependent pada variabel independent maka Heteroskedatik dapat terjadi. Adapun pengujian heteroskedastisitas dalam penelitian ini dilakukan dengan melihat titik persebaran pada diagram scatterplot. 2) Uji multikolinieritas dilakukan dengan menguji korelasi diantara variabel-variabel independent dengan korelasi sederhana. Indikasi multikolinearitas ditunjukkan dengan nilai tolerance dan variance inflation factors (VIF). Tidak terjadi multikolinieritas jika nilai VIF lebih kecil dari 10.3) Pengujian autokorelasi bertujuan untuk mengetahui ada tidaknya korelasi antara variabel pengganggu pada variabel tertentu dengan variabel sebelumnya. 4) Uji linieritas merupakan pengujian asumsi klasik dalam regresi yang bertujuan untuk menguji keterkaitan antara dua variabel yang bersifat linier. 5) Uji normalitas adalah sebuah pengujian yang dilakukan pada model regresi variabel independent dan dependent untuk melihat apakah dalam model ini mempunyai distrik normal atau tidak.

Uji model dilakukan terhadap nilai Koefisien Deteminasi (R-Squared/R2) yang bertujuan untuk melihat seberapa mampukan variabel independen dapat menjelaskan variabel dependen yang dilihat dari besarnya nilai persentase Rsquared $\left(\mathrm{R}^{2}\right)$. Pengujiannya dilakukan dengan uji $\mathrm{F}$ yaitu dipakai untuk menguji apakah segala variable independent yang dipakai dalam model regresi secara layak untuk menjelaskan pengaruhnya terhadap variable dependen. Apabila F hitung lebih besar daripada $\mathrm{F}$ table dan nilai sig. $<0,1$ maka seluruh variable independent berdampak kepada variable dependen, begitu pula sebaliknya.

Pengujian hipotesis satu, dua, dan tiga mengenai dampak dari masing-masing variable independent terhadap variable dependen diuji menggunakan uji t dengan tingkat signifikasi sebesar $10 \%$ dan $\mathrm{df}=\mathrm{n}-\mathrm{k}$. Uji $t$ ini dikerjakan menggunakan metode yang membandingkan nilai $t$ hitung dengan nilai $t$ table. Jika nilai t hitung lebih besar daripada $t$ table maka Ho akan ditolak, hal ini berarti ada relasi signifkan antara masing-masing variabel independent dengan dependen.

\section{HASIL DAN PEMBAHASAN \\ Hasil Penelitian}

Nilai Rhitung untuk seluruh indikator pada masing-masing variabel penelitian dalam penelitian ini adalah lebih besar dari Rtabel sebesar 0,2303. Ini menjelaskan segala instrument penelitian ini adalah valid.

Tabel 1. Uji Realibilitas

\begin{tabular}{|c|c|c|c|}
\hline Variabel & $\begin{array}{c}\text { Cronbach's } \\
\text { Alpha }\end{array}$ & Alpha & $\begin{array}{l}\text { Kete- } \\
\text { rangan }\end{array}$ \\
\hline $\begin{array}{l}\text { Kinerja } \\
\text { Pegawai }\end{array}$ & 0.926 & 0.6 & Reliabel \\
\hline $\begin{array}{l}\text { Kecerdasan } \\
\text { Intelektual }\end{array}$ & 0.918 & 0.6 & Reliabel \\
\hline $\begin{array}{l}\text { Kecerdasan } \\
\text { Emosional }\end{array}$ & 0.869 & 0.6 & Reliabel \\
\hline $\begin{array}{l}\text { Kecerdasan } \\
\text { Spiritual }\end{array}$ & 0.885 & 0.6 & Reliabel \\
\hline $\begin{array}{c}\text { Sumber: Data } \\
\text { Tabel } \\
\text { cronbach a } \\
\text { variabel leb } \\
\text { bahwa selur }\end{array}$ & $\begin{array}{l}\text { a primer, diolal } \\
1 \text { menjelask } \\
\text { lpha pada } \\
\text { oih besar da } \\
\text { ruh variabel }\end{array}$ & $\begin{array}{l}\text { h(2020) } \\
\text { an bah } \\
\text { masin } \\
\text { ari } 0,6 \text {. } \\
\text { dalam p }\end{array}$ & $\begin{array}{l}\text { wa nilai } \\
\text { g-masing } \\
\text { Artinya, } \\
\text { enelitian }\end{array}$ \\
\hline
\end{tabular}


ini reliabel dan handal sehingga dapat dilakukan pengujian menggunakan model analisis regresi linier berganda.

Tabel 2. Uji Normalitas KolmogorovSmirnov

\begin{tabular}{llr}
\hline & & $\begin{array}{c}\text { Unstandardiz } \\
\text { ed Residual }\end{array}$ \\
\hline $\mathrm{N}$ & & 73 \\
\hline Normal & Mean & .0000000 \\
\cline { 2 - 3 } Parameters $\mathrm{a}, \mathrm{b}$ & Std. & .21586317 \\
& Deviation & .06 \\
\hline
\end{tabular}

\begin{tabular}{llr}
\hline Most ExtremeAbsolute & .061 \\
\cline { 2 - 3 } Differences & Positive & .061 \\
\cline { 2 - 3 } & Negative & -.054 \\
\hline
\end{tabular}

Test Statistic $\quad .061$

Asymp. Sig. (2-tailed) $\quad .200$

Sumber: Data primer, diolah (2020)

Pada Tabel 2. dijelaskan bahwa nilai sig. pada pengujian Kolmogorov adalah sebesar 0,200 yakni lebih besar dari 0,05. Hal ini menunjukkan bahwa data dalam penelitian ini berdistribusi secara normal dan terhindar dari asumsi normalitas.

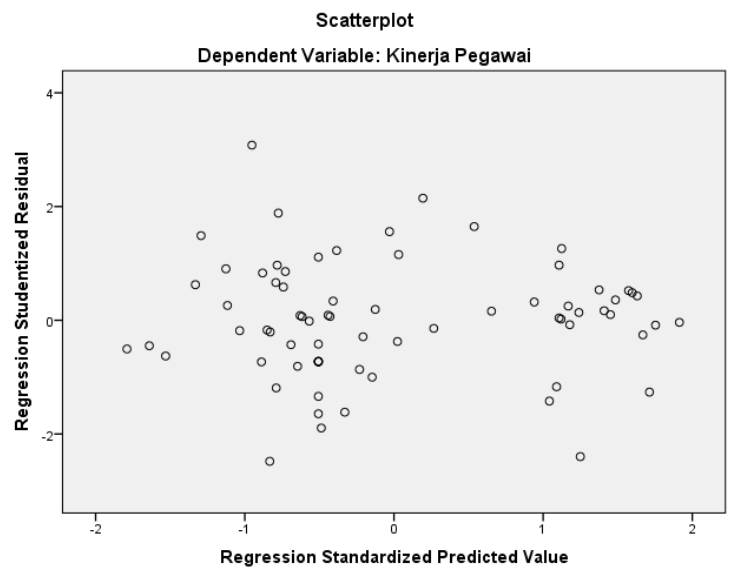

Gambar 1. Uji Heteroskedatisitas (scatterplot)

Pada Gambar 1 dapat dijelaskan bahwa titik persebaran pada scatterplot menyebar dengan tidak membentuk suatu pola. Hal ini menunjukkan bahwa variabel dalam penelitian ini homogen dan terhindar dari penyakit asumsi klasik heteroskedastisitas.

Tabel 3. Uji Multikolinieritas

\begin{tabular}{lcc}
\hline & \multicolumn{2}{c}{$\begin{array}{c}\text { Collinearity } \\
\text { Statistics }\end{array}$} \\
\cline { 2 - 3 } Model & Tolerance & VIF \\
\hline Kecerdasan Intelektual & .449 & 2.229 \\
\hline Kecerdasan Emosional & .299 & 3.350 \\
\hline Kecerdasan Spiritual & .340 & 2.941
\end{tabular}

Sumber: Data primer, diolah (2020)

Berdasarkan Tabel 3 dapat dijelaskan bahwa nilai VIF pada masing-masing variable berada dibawah 10 . Hal ini menampilkan bahwa variable penyusun yang dipakai terhindar dari penyakit asumsi klasi multikolinieritas dan sangat baik untuk dilakukan pengujian dengan model analisis regresi linier berganda.

Penelitian ini mendapatkan nilai Durbin Watson 1,771. Nilai tersebut berada pada di antara 1,5 dan 2,5 $(1,5<1,771<2,5)$. Artinya bahwa tidak terjadi autorelasi pada penelitian ini.

Berdasarkan Tabel 4 dapat dijelaskan bahwa nilai sig. linieritas antara kecerdasan intelektual dan kinerja pegawai adalah 0,178 yakni lebih besar dari 0,05. Artinya, antara variabel kecerdasan intelektual dan kinerja karyawan memiliki hubungan linier.

Pada Tabel 5 dijelaskan bahwa nilai sig. linieritas antara kecerdasan emosional dan kinerja pegawai adalah 0,634 yakni lebih besar dari 0,05. Artinya, antara variabel kecerdasan emosional dan kinerja karyawan memiliki hubungan linier.

Pada Tabel 6 juga dijelaskan bahwa nilai sig. linieritas antara kecerdasan spiritual dan kinerja pegawai adalah 0,095 yakni lebih besar dari 0,05. Artinya, antara variabel kecerdasan spiritual dan kinerja karyawan memiliki hubungan linier. 
Tabel 7. Hasil Regresi Linier Berganda Uji F

\begin{tabular}{llccccc}
\hline & Model & Sum of Squares & df & Mean Square & F & Sig. \\
\hline 1 & Regression & 8.871 & 3 & 2.957 & 60.816 & $.000^{\mathrm{b}}$ \\
& Residual & 3.355 & 69 & .049 & & \\
Total & 12.226 & 72 & & & \\
\hline
\end{tabular}

a. Dependent Variable: Kinerja Pegawai

b. Predictors: (Constant), Kecerdasan Spiritual, Emosional, Intelektual

Sumber: Data primer, diolah (2020)

Tabel 8. Hasil Koefisien Determinasi

\begin{tabular}{ccccc}
\hline Model & $\mathrm{R}$ & R Square & Adjusted R Square & Std. Error of the Estimate \\
\hline 1 & $.852^{\mathrm{a}}$ & .726 & .714 & .2205 \\
\hline
\end{tabular}

Sumber: Data primer, diolah (2020)

Nilai F hitung variabel independen terhadap variabel dependen kinerja karyawan (Tabel 7) adalah sebesar 60,816 yakni lebih besar dari nilai $F$ hitung sebesar 3,129 dan nilai sig. = 0,000 yakni lebih kecil dari nilai alpha 0,1. Artinya, variabel independen kecerdasan intelektual, kecerdasan emosional, dan kecerdasan spiritual berpengaruh signifikan terhadap variabel dependen kinerja pegawai. Pada Tabel 8 dapat dijelaskan bahwa nilai $\mathrm{R}$ dalam penelitian ini adalah $\left(0,852^{2} \times 100\right)=72,6 \%$.

Tabel. 9 Regresi Linier Berganda

\begin{tabular}{|c|c|c|c|c|c|c|}
\hline & \multirow[t]{2}{*}{ Model } & \multicolumn{2}{|c|}{$\begin{array}{c}\text { Unstandardized } \\
\text { Coefficients }\end{array}$} & \multirow{2}{*}{$\begin{array}{c}\text { Standardized } \\
\text { Coefficients } \\
\text { Beta }\end{array}$} & \multirow[t]{2}{*}{$\mathrm{t}$} & \multirow[t]{2}{*}{ Sig. } \\
\hline & & B & Std. Error & & & \\
\hline \multirow[t]{4}{*}{1} & (Constant) & .760 & .270 & & 2.810 & .006 \\
\hline & IQ & .236 & .079 & .280 & 2.976 & .004 \\
\hline & EQ & .394 & .107 & .423 & 3.667 & .000 \\
\hline & SQ & .220 & .103 & .230 & 2.128 & .037 \\
\hline
\end{tabular}

Sumber: Data primer, diolah (2020)

Model persamaan regresi linier ganda: $\mathrm{KIN}=0,760+0,236(\mathrm{IQ})+0,394(\mathrm{EQ})+0,220(\mathrm{SQ})$

Nilai $t$ hitung dari kecerdasan intelektual terhadap kinerja pegawai adalah 2,976 lebih besar dari nilai $\mathrm{t}$ tabel sebesar 1,994 dan nilai sig $=0,004<0,1$ maka H0 ditolak dan $\mathrm{H} 1$ diterima. Artinya, kecerdasan intelektual secara parsial berpengaruh signifikan terhadap kinerja pegawai. 2) Nilai t hitung dari kecerdasan emosional terhadap kinerja pegawai adalah 3,667 lebih besar dari nilai t_tabel 
sebesar 1,994 dan nilai sig $=0,000<0,1$ maka H0 ditolak dan H2 diterima. Artinya, kecerdasan emosional secara parsial berpengaruh signifikan terhadap kinerja pegawai. 3) Nilai t hitung dari kecerdasan spiritual terhadap kinerja pegawai adalah 2,128 lebih besar dari nilai Ttabel sebesar 1,994 dan nilai sig $=0,037<0,1$ maka H0 ditolak dan H3 diterima. Artinya, kecerdasan spiritual secara parsial berpengaruh signifikan terhadap kinerja pegawai.

\section{Pembahasan \\ Kecerdasan intelektual terhadap kinerja}

Kecerdasan intelektual berpengaruh positif terhadap kinerja karyawan. Peningkatan kecerdasan intelektual dapat berdampak pada meningkatnya kinerja pegawai BPOM Aceh baik yang bekerja di Balai Besar POM maupun yang bekerja di Loka Aceh Tengah dan Aceh Selatan. Hasil penelitian ini juga sejalan dengan yang pernah dilakukan oleh Wiramiharja (2003) yaitu penelitian yang menjelaskan adanya hubungan positif dalam peningkatan kinerja pegawai jika kecerdasan tersebut bersifat kognitif. Pencapaiaan peningkatan kinerja pegawai dapat dilakukan dengan dilakukannya pelatihan guna meningkatkan kemampuan verbal dan non-verbal pegawai sehingga pegawai dapat melatih diri untuk mengembangkan potensi dan kecerdasan dalam bekerja. Dengan adanya peningkatan kecerdasan intelektual maka akan berdampak pada peningkatan kecerdasan dan spesialisasi dari masing-masing pegawai sehingga pegawai lebih menjadi produktif dan berkontribusi baik bagi BPOM Aceh khususnya. Indikator yang digunakan dalam kecerdasan intelektual adalah kemampuan figure, kemampuan verbal dan kemampuan numerik.

\section{Kecerdasan emosional terhadap kinerja}

Kecerdasan emosional berdampak positif terhadap kinerja pegawai. Secara umum, kecerdasan emosional merupakan suatu kemampuan mengetahui perasaan sendiri dan perasaan orang lain, serta menggunakan perasaan tersebut menuntun pikiran dan perilaku seseorang (Svyantek, 2003). Kecerdasan emosional dapat berupa kesadaran diri, pengaturan diri, motivasi, empati, dan keterampilan sosial akan menuntun pikiran dan perilaku seseorang. Seseorang yang memiliki Kecerdasan Emosional yang memadai akan memiliki pertimbangan yang lebih komprehensif dalam bersikap dan berperilaku sehingga akan bersikap dan berperilaku etis. Hasil penelitian ini didukung oleh penelelitian yang dilakukan Tri, Cahyo Wibowo. (2015) yang menunjukan bahwa kecerdasan emosional memberikan pengaruh yang signifikan terhadap kinerja pegawai. Dengan kecerdasan emosional seseorang mampu mengontrol diri agar dapat bekerja secara maksimal untuk mendapatkan hasil kerja yang baik. Sehingga dari hasil penelitian ini diharapkan seluruh pegawai BPOM Aceh baik yang ada di Banda Aceh, maupun yang bertugas di dua Loka lainnya dapat selalu meningkatkan kecerdasan emosional serta dengan kontrol yang ketat. Indikator yang digunakan dalam kecerdasan emosional adalah pengenalan diri, pengendalian diri, motivasi, dan empati.

\section{Kecerdasan spiritual terhadap kinerja}

Kecerdasan spiritual berpengaruh positif terhadap kinerja pegawai. Penelitian yang serupa juga dilakukan Choiriah, Anis. (2013) Hasil penelitiannya mendukung dari hasil penelitian ini yang memperoleh hasil bahwa kecerdasan spiritual mempengaruhi kinerja pegawai. 
Hal ini dapat diartikan bahwa dengan kecerdasan spiritual yang terdiri dari indikator kejujuran, keterbukaan dalam bekerja, mengenal kepribadian, mengutamakan keterlibatan peran dan spiritual non-dogmatis maka akan meningkatkan kinerja secara otomatis. Indikator yang digunakan dalam kecerdasan spiritual adalah mutlak jujur, keterbukaan, pengetahuan diri, fokus kontribusi, dan spitual non-dogmatis.

\section{KESIMPULAN}

Adapun kesimpulan dari penelitian ini adalah: 1. Kecerdasan intelektual, kecerdasan emosional, dan kecerdasan spiritual berpengaruh terhadap variabel dependen kinerja pegawai. 2. Kecerdasan emosional mempunyai pengaruh yang lebih dominan terhadap kinerja pegawai dibandingkan variabel kecerdasan lainnya. Sehingga dapat disimpulkan bahwa pentingnya melakukan peningkatan soft skill berupa pelatihan public speaking. 


\section{DAFTAR PUSTAKA}

Adjma, Djumarno, dan Nasikin. (2014). Analisis kecerdasan intelektual, kecerdasan emosional dan kecerdasan spiritual terhadap kinerja karyawan pada PT. Telkom Jakarta Selatan. Jakarta: Jurnal Manajemen Mutu Vol.13 No.1

Amilia, Silmy dan Purnama, Ridwan. (2016). Pengaruh Kecerdasan Emosional Terhadap Kinerja Pegawai PT. Indonesia Comnets Plus di Bandung. Journal of Business Management and Enterpreneurship Education. Vol. 1, No. 1

Armansyah. (2002). Intelligent Quotient, Emotioanl Quotient, dan Spritual Quotient Dalam Membentuk Perilaku Kerja. Jurnal Ekonomi dan Bisnis.

Choiriah, Anis. (2013). Pengaruh Kecerdasan Emosional, Kecerdasan Intelektual, Kecerdasan Spiritual, dan Etika Profesi Terhadap Kinerja Auditor dalam Kantor Akuntan Publik (Studi Empiris Pada Auditor dalam Kantor Akuntan Publik di Kota Padang dan Pekanbaru). Jurnal Universitas Negeri Padang,Vol.1, No.1

Ghozali, Imam. (2006). Analisis Multivariate dengan Program SPSS. Edisi Ke 4. Badan Penerbit Universitas Diponegoro. Semarang.

Goleman, Daniel. (2000). Kecerdasan Emosi: Mengapa Emotional Intelegence Lebih Tinggi dari pada IQ, Jakarta: PT. Gramedia Pustaka Utama.

Rahmasari, Lisda. (2012). Pengaruh kecerdasan intelektual, kecerdasan emosi dan kecerdasan spiritual terhadap kinerja karyawan. Makalah Ilmiah Informatika Vol.3 No. 1

Sibasopait, Aderharda Boru. (2018). Pengaruh Kecerdasan Intelektual, Kecerdasan Emosional, Dan Kecerdasan Spiritual Terhadap Kinerja Melalui Kepuasan Kerja Tenaga Kependidikan Di Kantor Pusat Universitas Jember. Jurnal Bisnis dan Manajemen, Vol.12 No. 2

Svyantek, D.J. (2003). Emotional Intellegence and Organitational Behavior. The International Journal of Organizational Analysis II (3): 167-169.

Tri, Cahyo Wibowo. (2015). Analisis Pengaruh Kecerdasan Emosional (EQ) dan Kecerdasan Spiritual (SQ) pada Kinerja Karyawan. Jurnal Bisnis \& Manajemen,Vol. 15, No. 1

Trihandini, R.A Fabiola Meirnayati. (2005). Analisis Pengaruh Kecerdasan Intelektual,Kecerdasan Emosi dan Kecerdasan Spiritual Terhadap Kinerja Karyawan (Studi Kasus di Hotel Horizon Semarang). Semarang: Tesis Program Pascasarjana Universitas Diponegoro.

Wibowo. (2007). Manajemen Kinerja. Edisi Kedua. Jakarta: PT. Raja Grafindo Persada.

Wiramiharja A. Sutardjo (2003). Keeratan Hubungan Antara Kecerdasan, Kemauan dan Prestasi Kerja, Jurnal Psikologi. Bandung

Zohar, Danah dan Marshall, Ian. (2000). Kecerdasan Spiritual (SQ). Cetakan ke IX. Bandung: PT. Mizan Pustaka. 
Tabel 4. Linieritas Kecerdasan Intelektual dengan Kinerja Pegawai

\begin{tabular}{|c|c|c|c|c|c|c|c|}
\hline & & & $\begin{array}{l}\text { Sum of } \\
\text { Squares }\end{array}$ & $\mathrm{df}$ & $\begin{array}{l}\text { Mean } \\
\text { Square }\end{array}$ & $\mathrm{F}$ & Sig. \\
\hline \multirow{5}{*}{$\begin{array}{l}\text { Kinerja Pegawai } \\
\text { * Kecerdasan } \\
\text { Intelektual }\end{array}$} & \multirow{3}{*}{$\begin{array}{l}\text { Between } \\
\text { Groups }\end{array}$} & (Combined) & 8.749 & 22 & .398 & 5.718 & .000 \\
\hline & & Linearity & 6.744 & 1 & 6.744 & 96.977 & .000 \\
\hline & & $\begin{array}{l}\text { Deviation from } \\
\text { Linearity }\end{array}$ & 2.005 & 21 & .095 & 1.373 & .178 \\
\hline & \multicolumn{2}{|c|}{ Within Groups } & 3.477 & 50 & .070 & & \\
\hline & \multicolumn{2}{|c|}{ Total } & 12.226 & 72 & & & \\
\hline
\end{tabular}

Sumber: Data primer, diolah (2020)

Tabel 5. Linieritas Kecerdasan Emosional dengan Kinerja Pegawai

\begin{tabular}{|c|c|c|c|c|c|c|c|}
\hline & & & $\begin{array}{l}\text { Sum of } \\
\text { Squares }\end{array}$ & $\mathrm{df}$ & $\begin{array}{l}\text { Mean } \\
\text { Square }\end{array}$ & $\mathrm{F}$ & Sig. \\
\hline \multirow{5}{*}{$\begin{array}{l}\text { Kinerja Pegawai } \\
* \quad \text { Kecerdasan } \\
\text { Emosional }\end{array}$} & Between & (Combined) & 8.512 & 11 & .774 & 12.707 & .000 \\
\hline & Groups & Linearity & 8.027 & 1 & 8.027 & 131.826 & .000 \\
\hline & & $\begin{array}{l}\text { Deviation from } \\
\text { Linearity }\end{array}$ & .484 & 10 & .048 & .795 & .634 \\
\hline & Within Gr & ups & 3.715 & 61 & .061 & & \\
\hline & Total & & 12.226 & 72 & & & \\
\hline
\end{tabular}

Sumber: Data primer, diolah (2020)

Tabel 6. Linieritas Kecerdasan Spiritual dengan Kinerja Pegawai

\begin{tabular}{|c|c|c|c|c|c|c|c|}
\hline & & & $\begin{array}{l}\text { Sum of } \\
\text { Squares }\end{array}$ & $\mathrm{df}$ & $\begin{array}{l}\text { Mean } \\
\text { Square }\end{array}$ & $\mathrm{F}$ & Sig. \\
\hline \multirow{5}{*}{$\begin{array}{l}\text { Kinerja Pegawai } \\
* \quad \text { Kecerdasan } \\
\text { Spiritual }\end{array}$} & \multirow{3}{*}{$\begin{array}{l}\text { Between } \\
\text { Groups }\end{array}$} & (Combined) & 8.269 & 12 & .689 & 10.446 & .000 \\
\hline & & Linearity & 7.033 & 1 & 7.033 & 106.623 & .000 \\
\hline & & $\begin{array}{l}\text { Deviation from } \\
\text { Linearity }\end{array}$ & 1.236 & 11 & .112 & 1.703 & .095 \\
\hline & \multicolumn{2}{|c|}{ Within Groups } & 3.958 & 60 & .066 & & \\
\hline & \multicolumn{2}{|c|}{ Total } & 12.226 & 72 & & & \\
\hline
\end{tabular}

Sumber: Data primer, diolah (2020) 